\title{
Bear maulings treated in Calgary, Alberta: Their management and sequelae
}

\author{
Ryan C Frank MD, Raman C Mahabir MD MSc, Enzio Magi MD FRCSC, \\ Robert L Lindsay MB ChB FRCSC, William de Haas MD FRCSC
}

\begin{abstract}
RC Frank, RC Mahabir, E Magi, RL Lindsay, W de Haas. Bear maulings treated in Calgary, Alberta: Their management and sequelae. Can J Plast Surg 2006;14(3):158-162.
\end{abstract}

BACKGROUND: Between 1994 and 2005, seven patients underwent surgery at the Foothills Medical Centre, Calgary, Alberta, for injuries sustained in bear maulings. The purpose of the present study was to document these cases and add to the literature on the management and the potential complications of bear attacks.

METHODS: Data were collected retrospectively from charts.

RESULTS: Seven patients were treated for injuries ranging from lacerations and puncture wounds to fractures and avulsed tissue. On average, patients underwent three operations and spent 22 days in hospital. Mean time from attack to arrival at the trauma centre was $19 \mathrm{~h}$. Irrigation, debridement and intravenous antibiotics did not prevent wound infections in two patients. Six of seven patients developed acute stress disorder, and one of these patients went on to suffer from post-traumatic stress disorder. Complications ranged from infection to pulmonary embolism.

CONCLUSIONS: Bear attacks result in a spectrum of injuries. Infections and psychiatric disorders are common sequelae.

Key Words: Animal attack; Black bear; Grizzly bear; Mauling; PTSD

Ghould I play dead or fight back? A question people would Sask themselves if suddenly faced with the most feared animal in the Canadian Rockies. Should your response differ if faced with a black bear as opposed to a grizzly bear? Dr Stephen Herrero, a Canadian authority on the subject, has addressed these issues, among others, in a recently published book (1).

Ursus americanus and Ursus arctos horribilis (black and grizzly bears, respectively) inhabit a large area of North America (1). Black bears can be found in approximately three-quarters of all land within Alberta, while grizzly bears inhabit only onethird (2). Estimates of the population of black bears $(38,160$ to $39,192)$ are more than 35 times that of grizzly bears (1035 to 1075), yet grizzly bear attacks have been reported to be 10 times more common than black bear attacks $(1,2)$. The goal of the present study was to document the injuries suffered in bear maulings and to add to the literature on the management and the potential complications of these traumatic events.

\section{METHODS}

A total of 345 charts were reviewed at the four major hospitals in the Calgary Health Region (Foothills Medical Centre [FMC],

\section{Traitement et séquelles des blessures infligées par des ours - Calgary, Alberta}

\begin{abstract}
HISTORIQUE : Entre 1994 et 2005, au Foothills Medical Centre de Calgary, en Alberta, sept patients ont subi des chirurgies à la suite de blessures infligées par des ours en liberté. Le but de la présente étude était de documenter ces cas et de décrire la prise en charge et les complications potentielles des blessures infligées à des être humains par des ours.

MÉTHODE : Les données ont été recueillies de manière rétrospective à partir des dossiers.

RÉSULTATS : Sept patients ont été traités pour des blessures allant de lacérations et perforations à des fractures avec avulsion. En moyenne, les patients ont subi trois interventions et passé 22 jours à l'hôpital. Le délai moyen entre l'attaque et l'arrivée au centre de polytraumatologie a été de 19 h. L'irrigation, le débridement des plaies et l'antibiothérapie intraveineuse n'ont pas empêché les infections de survenir chez deux patients. Six patients sur sept ont développé un syndrome de stress post-traumatique aigu. Les autres complications ont varié de l'infection à l'embolie pulmonaire.
\end{abstract}

CONCLUSION : Les lésions infligées par des ours sont de nature diverse. Les infections et les troubles psychiatriques en sont des séquelles courantes.

Peter Lougheed Centre, Rockyview Hospital and Alberta Children's Hospital), Alberta, with a diagnostic code of animal attacks between January 1, 1994 and December 31, 2004. Of these, only seven pertained specifically to bear attacks, and all were treated at the FMC. Data concerning activity preceding attack, region, type and date of attack, type and sex of bear, patient demographics, time from attack to first medical treatment, time from attack to hospital, type and severity of injury, operations, transfusions, length of hospital stay and complications were extracted from the patient charts. The present study received approval from the University of Calgary Health Research Ethics Committee and has adhered to all established guidelines in terms of patient rights and confidentiality.

\section{RESULTS}

Seven patients, aged 21 to 73 years (mean age 43 years), were treated for injuries sustained in bear maulings over a 10 -year period. All patients were admitted and underwent surgery. Six of the seven attacks were by grizzly bears. Of the six grizzly bear attacks, four were defensive in nature and two were predacious. The lone black bear attack was predacious. A summary of the

Division of Plastic Surgery, Department of Surgery, University of Calgary, Calgary, Alberta

Correspondence: Dr RL Lindsay, 101-7 Glenbrook Place Southwest, Calgary, Alberta T3E 6W4. Telephone 403-571-3155, fax 403-571-3159, e-mail rllindsa@ucalgary.ca 
TABLE 1

Summary of patient demographics, date and type of attack, and time to treatment

\begin{tabular}{|c|c|c|c|c|c|c|c|c|c|}
\hline Patient & Age & Sex & Activity & Area & $\begin{array}{c}\text { Month } \\
\text { of attack }\end{array}$ & Type of attack & Type of bear & $\begin{array}{c}\text { Time from attack to } \\
\text { initial hospital treatment }\end{array}$ & $\begin{array}{c}\text { Time from } \\
\text { attack to FMC }\end{array}$ \\
\hline 1 & 21 & $\mathrm{M}$ & Camping & Lake Louise, AB & September & Predacious & Grizzly bear & 1.75 h (Banff, AB) & $4.25 \mathrm{~h}$ \\
\hline 2 & 21 & $M$ & Camping & Lake Louise, AB & September & Predacious & Grizzly bear & 1.75 h (Banff, AB) & $5 \mathrm{~h}$ \\
\hline 3 & 28 & $M$ & Picnic & Laird Hot Springs, BC & August & Predacious & Black bear & $2 \mathrm{~h}$ (Fort Nelson, BC) & $23 \mathrm{~h}$ \\
\hline 4 & 64 & $M$ & Hiking & Pincher Creek, AB & July & Defensive & Grizzly bear & $7 \mathrm{~h}(\mathrm{FMC})$ & $7 \mathrm{~h}$ \\
\hline 5 & 39 & $M$ & $\begin{array}{l}\text { Hunting grizzly } \\
\text { bears }\end{array}$ & Golden, BC & May & Defensive & Grizzly bear & 14.75 h (Golden, BC) & $19 \mathrm{~h}$ \\
\hline 6 & 53 & $\mathrm{~F}$ & Hunting moose & Kananaskis, AB & October & Defensive & Grizzly bear & $3 \mathrm{~h}(\mathrm{FMC})$ & $3 \mathrm{~h}$ \\
\hline 7 & 73 & $M$ & Hunting moose & McBride, BC & October & Defensive & Grizzly bear & $2 \mathrm{~h}$ (McBride, BC) & $72 \mathrm{~h}$ \\
\hline
\end{tabular}

AB Alberta; BC British Columbia; FMC Foothills Medical Centre, Calgary, AB

patient demographics, date and type of attack, and the time between attack and medical treatment is presented in Table 1.

\section{Injuries}

The injuries and operations sustained by the seven patients are reported in Table 2. All patients suffered numerous lacerations, puncture wounds and soft tissue injuries. Patient 2 suffered a fractured medial epicondyle with an associated ulnar neuropraxia, and a degloving of tissue from the left forearm extensor compartment. Patient 4 suffered a complex left-sided facial injury, including extensive damage to the eye, a maxillary fracture and a fracture of the right fourth metacarpal. Patient 5 suffered a frontal bone fracture with an underlying dural tear, multiple other facial fractures and a large soft tissue avulsion from the nasal region. Patient 6 suffered a facial nerve laceration. Patient 7 suffered a complex, right-sided facial injury, including extensive damage to the eye, and maxillary and orbit fractures (Figure 1).

Operations, transfusions and length of hospital stay Patients initially underwent extensive irrigation and debridement of lacerations and abrasions. Puncture wounds were excised and thoroughly irrigated. All patients had scar revisions. Details of each patient's operations are summarized in Table 2. On average, the patients had three operations (range one to eight operations), were given two units of blood (range zero to six units), and spent 22 days in hospital (range six to 52 days) (Table 3).

\section{Complications}

Complications are also summarized in Table 2. Acute stress disorder was diagnosed in six patients. This psychological condition required counselling and pharmacological treatment. Patients 1 and 2 suffered no other complications. Patient 3 was diagnosed with a deep venous thrombus and pulmonary embolus requiring readmission. Patient 4's acute stress disorder progressed to post-traumatic stress disorder (PTSD), requiring further psychiatric intervention. This was manifest as depression and sleep disturbance more than six months postattack. This patient also had a facial and orbital infection requiring treatment and a tissue expander rupture requiring replacement. Patient 5 had positive scalp cultures that were treated with antibiotics. A posterior scalp defect that remained open for two months was eventually closed with local flaps. Chronic left medial strabismus persisted despite ophthalmological intervention. Patient 7 had an episode of oxygen desaturation in his second operation as a result of methemoglobinemia. This patient also experienced intermittent atrial fibrillation and paroxysmal supraventricular tachycardia. These conditions were transient and were not present at the time of discharge.

\section{Bacterial growth}

All patients received broad-spectrum antibiotics. The patients who were seen in the periphery before transfer to the FMC (patients 1, 2, 3, 5 and 7) received at least one dose of a cephalosporin before transfer. Patients 1, 2, 3, 6 and 7 had negative cultures. Patient 4 grew Proteus mirabilis and Candida albicans one month after admission to hospital and was treated with cefazolin/metronidazole and tobramycin drops. Patient 5 grew Morganella morganii and an Enterococcus species from a scalp culture performed 11 days after admission to hospital. No change in the antibiotic regimen was required and the infection was successfully treated.

\section{DISCUSSION}

The two major types of bear attacks are defensive and predatory $(1,3,4)$. Defensive attacks are the result of abrupt, unexpected encounters that follow in response to a perceived threat to cubs, individual space or food supply, and often involve activities such as hiking and hunting. Predacious attacks are far less common and occur when humans are perceived as a source of food. In these instances, the bear more often invades human territory, eg, camping or picnicking sites. Predacious attacks result in the majority of fatal encounters $(1,2)$.

Bear encounters frequently do not result in attacks (1). Often, humans are able to either scare the bear away or successfully escape the bear (1). If suddenly confronted with a grizzly bear at close range (200 m or closer), one should stand his or her ground and make plenty of noise in attempt to scare the bear away (1). If the encounter is at longer range (200 $\mathrm{m}$ or farther), it is advised to climb a large tree and wait for at least $15 \mathrm{~min}$ after the bear is out of sight before climbing back down (1).

Occasionally, initial scare tactics are unsuccessful and an attack is unavoidable (1). It is then vital for the person being attacked to understand which form of attack the bear is displaying (1). It has been strongly suggested by Dr Herrero that the right thing to do during a defensive attack is to play dead. The intensity of a bear attack will, more often than not, decrease when the person being attacked assumes a motionless and defensive position (1). This involves positioning oneself facedown, with hands behind the neck and legs spread apart to 
TABLE 2

Summary of injuries, operations and complications

\begin{tabular}{|c|c|c|c|}
\hline Patient & Injuries & Operations & Complications \\
\hline \multirow[t]{5}{*}{1} & $\begin{array}{l}\text { Lacerations to scalp, back, shoulders, upper } \\
\text { arms, flanks, buttocks, thighs and L heel }\end{array}$ & 1: I/D; STSG to R arm & ASD \\
\hline & Puncture wounds to back, extending into & & \\
\hline & latissimus dorsi & & \\
\hline & $\mathrm{R}$ proximal arm soft tissue injury & & \\
\hline & $\mathrm{R}$ renal contusion & & \\
\hline
\end{tabular}

2 Soft tissue injuries sustained to R shoulder, elbow,

1: I/D; ORIF of R medial epicondyle; exploration

forearm, hip, buttocks, knee and foot, $L$ forearm

$\mathrm{R}$ displaced medial epicondyle

R ulnar neuropraxia

$R$ back lacerations

$\mathrm{L}$ forearm extensor compartment degloving

Abrasions to all extremities
Puncture wounds to shoulders, R thigh and scalp
L thigh sustained large tissue avulsion injury
Shear injuries to thigh musculature

$4 \quad$ Lacerations to hands, scalp, forehead and eyelids

$R$ 4th metacarpal fracture

$L$ facial tissue avulsion

L eye rupture

Maxilla fractures bilaterally
1: I/D; exploration of neurovascular bundle

2: I/D

3: I/D; STSG of $L$ thigh defect repair upper/lower eyelids; removal of $L$ eye

2: Tissue expander insertion to forehead

3: I/D of facial/eye wounds; conjunctival skin graft with repair
$\mathrm{R}$ ulnar nerve; tendon/muscle repair of

ASD

L forearm
ASD; Deep vein thrombosis and

pulmonary embolism

1: I/D; explore ulnar digital nerve and ORIF R 4th metacarpal; PTSD; tissue expander rupture; STSG to scalp and forehead; ORIF of maxillary fractures; wound infection with of lacrimal system; bone graft; free radial forearm flap for coverage of $L$ cheek; STSG to nasal/orbital cavity

4: Tissue expander replacement

5: Total nasal reconstruction with forehead flap over calvarial bone graft

6: Division of forehead flap

7: L unilateral brow lift; revision forehead flap; Weir excision $\mathrm{R}$ alar base

8: Removal of hardware; revision of forehead flap

5 Lacerations to supraorbital region and posterior scalp

Punctures on $\mathrm{R}$ hand, thigh and skull

Frontal bone fracture

$\mathrm{L}$ maxilla/mandible/zygoma fracture

Nasal ethmoid fracture with degloving of nasa tissue
1: I/D; obliteration of frontal sinus; dural repair; ORIF of facial ASD; wound infection with fractures with bone graft to orbital floor; scalp rotation flap closure; exploration facial nerve

2: Scar revision

3: Transposition of $L$ superior and inferior rectus to $L$ lateral rectus (ophthalmology)

4: Removal of hardware; scar revision

5: Scar revision; L medial rectus resection (ophthalmology)

6: Insertion of silicone prosthesis in $L$ temple; release of $\mathrm{L}$ lateral palpebral fissure; brow lift
Proteus mirabilis and Candida albicans
Morganella morganii and an Enterococcus species; posterior scalp wound remained open for two months: persistent medial strabismus in $L$ eye

1: I/D; ORIF of left zygoma; explore left facial nerve; $\quad$ None
closure of wounds

2: Repair left facial nerve

$L$ facial nerve injury

Punctures to R shoulder, R groin, L breast

\begin{tabular}{lll}
\hline & $R$ face degloving $1: I / D ;$ exploration of right eye
\end{tabular}

Complete transection of nose and nasal septum

Comminuted fractures of bilateral maxilla and orbit

R Le Fort III fracture

Lacerations to face, hands, left thigh, posterior shoulders, scalp, R sclera
2: Maxillofacial reconstruction - interrupted due to oxygen desaturation

3: Tracheostomy; completion of maxillofacial reconstruction (orbital floor mesh, medial wall bone graft, medial and lateral canthoplasties, resuspension midface soft tissues); exploration of right facial nerve; intermaxillary fixation; closed reduction of nasal bones

\author{
ASD; oxygen desaturation during \\ initial maxillofacial reconstruction \\ (due to high methemoglobin \\ levels); intermittent \\ atrial fibrillation and \\ paroxysmal supraventricular \\ tachycardia
}




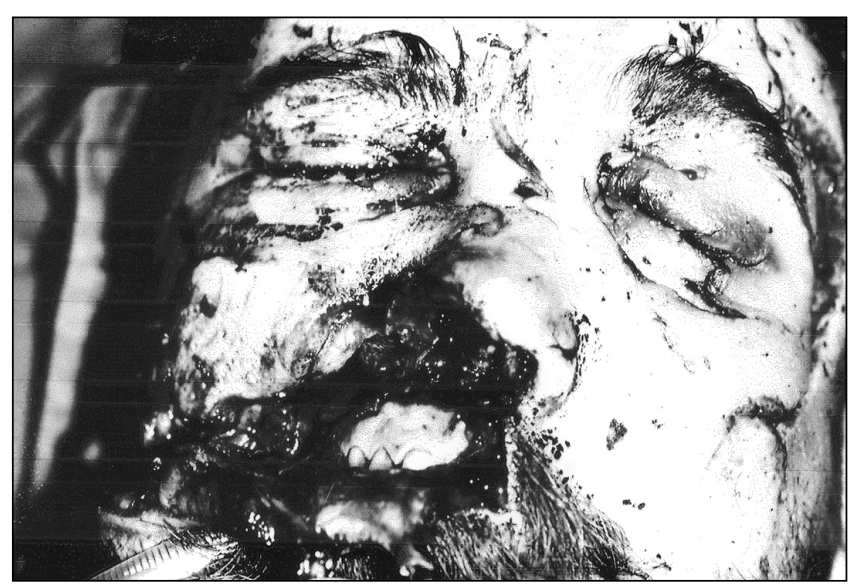

Figure 1) Face of patient 7 shortly after arrival to Foothills Medical Centre, Calgary, Alberta

TABLE 3

Days in hospital, number of operations and total units of blood transfused

\begin{tabular}{lccc}
\hline Patient & $\begin{array}{c}\text { Total days } \\
\text { in hospital }\end{array}$ & $\begin{array}{c}\text { Total number } \\
\text { of operations }\end{array}$ & $\begin{array}{c}\text { Total units } \\
\text { transfused }\end{array}$ \\
\hline 1 & 8 & 1 & 2 \\
2 & 6 & 1 & 0 \\
3 & 28 & 3 & 4 \\
4 & 52 & 8 & 0 \\
5 & 21 & 6 & 6 \\
6 & 10 & 2 & 0 \\
7 & 30 & 3 & 2 \\
Mean & 22 & 3 & 2 \\
\hline
\end{tabular}

prevent the bear from turning the victim over (1). Only as a last resort and when it is clear that the bear has entirely predacious and aggressive intentions are the use of weapons and/or fists or kicks suggested (1).

Of the six grizzly bear attacks in the present study, two were predacious and four were defensive. The victims of the defensive attacks were hiking and hunting. The victims of the predacious attacks were camping. Interestingly, the predacious attacks were less serious than the defensive attacks in terms of injuries sustained and operations required. This is in contrast to the expected severity. Perhaps the predacious attacks occurred as a result of the bear looking for campers' food and not the campers themselves. Another possibility is that act of playing dead was successfully achieved by these victims. It is important to note that individual bear activity or behaviour is extremely difficult to predict (1). Therefore, the actions of the victim may be completely irrelevant in determining the severity of the bear attack.

The majority of the wounds sustained by the victims (defensive or predacious attacks) in the present study involved the head and extremities. This is consistent with previously documented attacks (1). Aggression is directed toward the head, because in confrontations between bears, each bear attempts to bite the other's face and jaw to disable the opponent's powerful weapon (1). It is common to sustain facial and even skull fractures during an attack, but it is uncommon to receive a skull penetration injury, as sustained by patient 5 . This

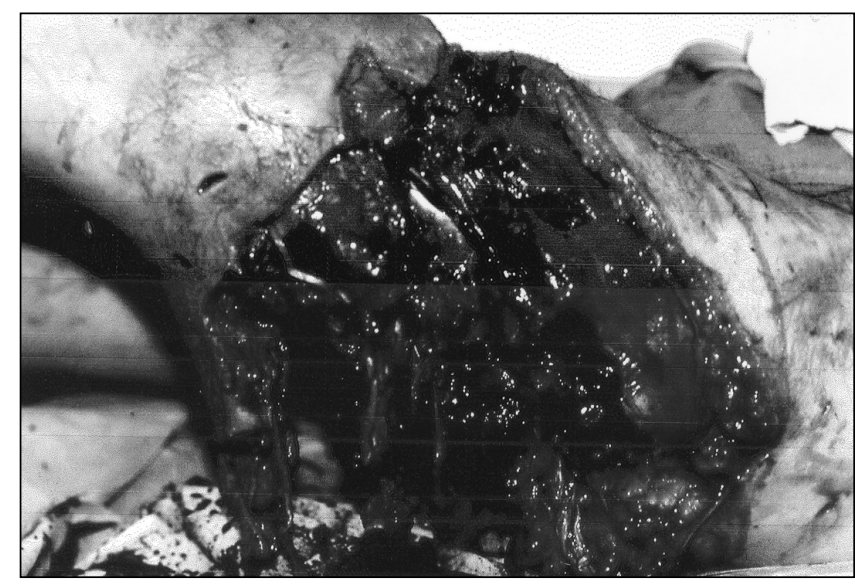

Figure 2) Left thigh wound of patient 3

is because the mouth of the bear is typically not wide enough to engulf the entire length of the face of the victim. This injury may have been the result of an oblique angle of entry of the teeth into the frontal bone not ordinarily achieved.

The black bear attack differed from the grizzly bear attacks in that the black bear mauled the victim's proximal thigh (Figure 2). It is unclear whether this is a common site of attack for black bears. Although serious, black bear attacks are rare; when they do occur, the majority of victims die (1).

Infection is a common problem following bear attacks $(3,5)$. The grizzly bear has numerous Gram-positive and Gramnegative flora within its mouth (6). While a few studies have investigated the organisms grown in wounds following grizzly bear attacks $(3,5)$, none have looked at wounds following black bear attacks. In a similar study by Mahabir et al (5), multiple organisms were cultured in all four bear attack victims' wounds. Organisms cultured in that study were consistent with the current study. The injuries in the study by Mahabir et al were more extensive than those in the current study, perhaps explaining the increased infection rate. Other factors such as age of victim, time to treatment and depth of wound may play parts in this discrepancy as well. Unfortunately, the small numbers negate meaningful comparison.

The victims in the present study who received a dose of a second- or third-generation cephalosporin within $3 \mathrm{~h}$ postattack had no infection (4). The patients who did not receive any antibiotics for $7 \mathrm{~h}$ (patient 4) or $14.75 \mathrm{~h}$ (patient 5) had wound infections. All patients received broad-spectrum antibiotics while at the FMC. The patients with positive cultures had the most severe attacks of the five patients, and they did not receive antibiotics until much later than the other three patients. Hence, prophylactic antibiotics may aid in preventing infection.

Psychiatric complications are common following trauma (7). PTSD is defined as development of symptoms lasting longer than one month following emotional stress associated with trauma (7). These symptoms include depression, anxiety and cognitive difficulties (7). If these symptoms persist for less than one month following emotional stress, a diagnosis of acute stress disorder can be made (7). Both conditions are frequently treated with a combination of antidepressants and psychotherapy (7). All patients in this study had disturbances of 
sleep within days of admission. Patients 1, 2, 3, 5, 6 and 7 did not have symptoms long or severe enough to diagnose PTSD. Patient 4, however, did meet the criteria. These results are in contrast with Mahabir et al's study, in which all four patients were diagnosed with PTSD. Again, perhaps due to the severity of those attacks, one could conclude that the patients in that study were more prone to the development of PTSD. Again, it is difficult to accurately compare results due to the small number of victims. Because most patients in the present study developed acute stress disorder, early psychiatric involvement in patient care is recommended.

\section{CONCLUSIONS}

The present study lends support to earlier conclusions that bear attack victims constitute a unique group of patients. Initial assessment must consider the complex nature of these injuries. Treatment requirements may exceed the resources of a small centre. Early, broad-spectrum antibiotics, along with irrigation and debridement of wounds, may be of benefit. A multidisciplinary approach to treatment should involve the psychiatry team, because acute stress disorder was universal throughout this patient population. Increased severity of injury appeared to correlate with a higher rate of infection.

\section{REFERENCES}

1. Herrero S. Bear Attacks: Their Causes and Avoidance, New Revised Edition. Toronto: McClelland and Stewart Ltd, 2003.

2. Herrero S, Higgins A. Human injuries inflicted by bears in Alberta: 1960-98. Ursus 2003;14:44-54.

3. Thommasen HV, Shelton G, Trites AW. Bear maulings in British Columbia. BC Med J 1994;36:745-8.

4. Middaugh JP. Human injury from bear attacks in Alaska, 19001985. Alaska Med 1987;29:121-6.

5. Mahabir R, Olesen PR, Cannon WG, et al. Surgical management of injuries sustained from grizzly bear maulings treated in Vancouver, British Columbia. Can J Plast Surg 2000;8:193-8.

6. Parry RG, Ziemis R, Reynolds H, Miller S. Brown/Grizzly bear mouth cultures in Alaska. Alaska Med 1983;25:1-2.

7. Kaplan HI, Saddock BJ, Grebb JA. Synopsis of Psychiatry: Behavioral Sciences, Clinical Psychiatry, 7th edn. Baltimore: Williams \& Wilkins, 1994:608-11. 